American Journal of Environmental Sciences 7 (3): 276-285, 2011

ISSN 1553-345X

(C) 2011 Science Publications

\title{
A Review of Integrated River Basin Management for Sarawak River
}

\author{
${ }^{1}$ Kuok King Kuok, ${ }^{2}$ Sobri Harun and ${ }^{3}$ Po-Chan Chiu \\ ${ }^{1}$ School of Engineering, Computing and Science, Swinburne University \\ of Technology Sarawak Campus, Jalan \\ Simpang Tiga, 93350 Kuching, Sarawak, Malaysia \\ ${ }^{2}$ Department of Hydraulics and Hydrology, Faculty of \\ Civil Engineering, University Technology Malaysia, \\ 81310 UTM Skudai, Johor, Malaysia \\ ${ }^{3}$ Department of Information System, Faculty of Computer \\ Science and Information Technology, University Malaysia \\ Sarawak, 94300 Samarahan, Sarawak Malaysia
}

\begin{abstract}
Problem statement: Sarawak River was a life-sustaining water source for the residents in Kuching City and surrounding areas. Raw water is treated at Batu Kitang Water Treatment Plant (BKWTP) that supplies more than $98 \%$ of the total water production in Kuching City. The raw water supply to BKWTP is not adequate to meet the ever increasing water demand. In order to overcome this problem, four projects had been implemented along Sarawak River for managing and securing water supply to BKWTP. Approach: These four projects are construction of $1.5 \mathrm{~m}$ height storage weir across Sungai Sarawak Kiri river channel, Kuching Barrage and Shiplock, Bengoh Dam and Kuching Centralized Wastewater Management System (KCWMS). In 2005, $1.5 \mathrm{~m}$ height submersible weir was constructed across Sungai Sarawak Kiri channel for increasing the safe yield that can last until year 2010. Kuching Barrage and Shiplock were commissioned in 2000 as barrier to avoid the saline intrusion reaching upper catchment. 24 telemetry stations were installed along Sarawak River for monitoring and regulating the water level. This will preserve high quality water storage at upper catchment of Sarawak River. In year 2010, Bengoh Dam was constructed to ensure adequate raw water will be supplied to BKWTP for meeting the increasing water demand from 2010-2030. This reservoir will store 144 million $\mathrm{m}^{3}$ of fresh water covering reservoir area of $8.77 \mathrm{~km}^{2}$. Beyond 2030 , the water supply shall not depend solely on fresh water. Results: Black and grey water in Sarawak Catchment was treated through Kuching Centralized Wastewater Management System (KCWMS) and recycled for daily used. Conclusion: The treated water that comply Standard A water quality, can distribute for domestic, industrial and irrigation used in nearest future. This will reduce the water demand solely on raw water and create a sustainable living in Kuching City. Beyond 2030, a few alternatives are also proposed for conserving and securing water supply for Kuching city.
\end{abstract}

Key words: Batu Kitang Water Treatment Plant (BKWTP), batu kitang submersible weir, kuching barrage and shiplock, Kuching Centralize Wastewater Management System (KCWMS), tourism industry, water treatment plants

\section{INTRODUCTION}

Sarawak River is lifeblood of Kuching city, the state capital of Sarawak, Malaysia. This river serves as a life-sustaining water source for the residents in Kuching City and surrounding areas. The raw water draw from Sarawak River will be treated at Batu Kitang Water Treatment Plant (BKWTP) before distributing for domestic and industrial used. Besides, Sarawak
River is an important navigation channel that connected a few landmarks in Kuching City using River Taxi. The river also used for water related sport activities such as Sarawak Regatta, to boast the tourism industry. During raining season, Sarawak River is also function as flood mitigation tool with the operation of Kuching Barrage and Shiplock. Meanwhile, Sarawak River collected all the stormwater and wastewater from the drains and tributaries before discharge into South China Sea.

Corresponding Author: Kuok King Kuok, School of Engineering, Computing and Science, Swinburne University of Technology Sarawak Campus, Jalan Simpang Tiga, 93350 Kuching, Sarawak, Malaysia 


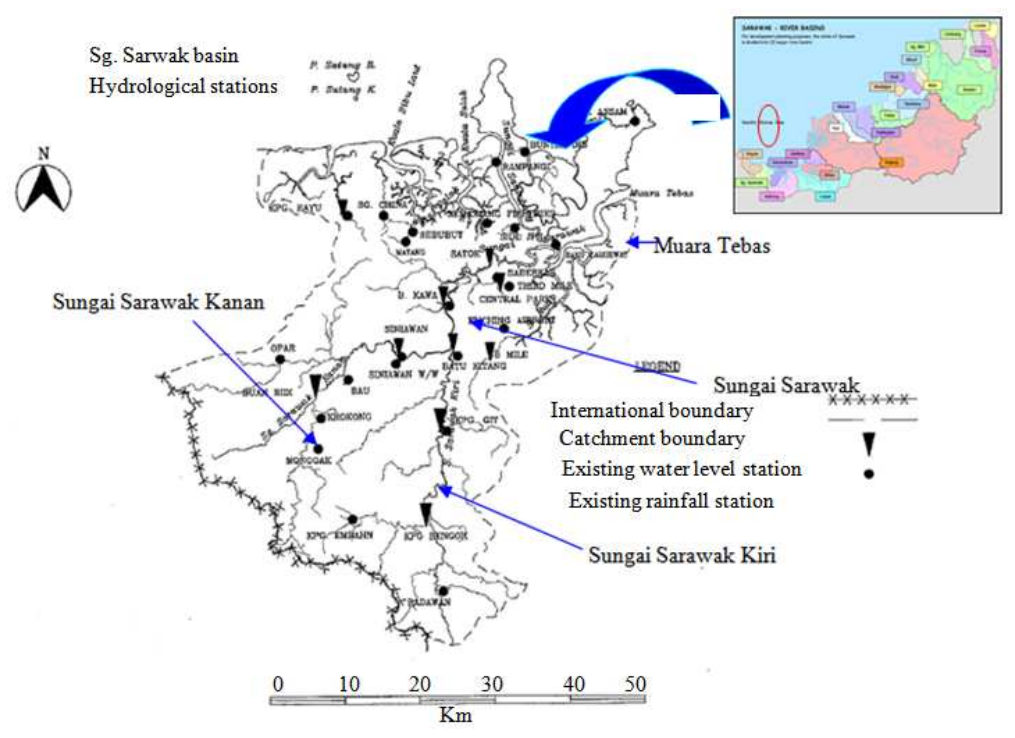

Fig. 1: Sarawak River Basin (Gandaseca et al., 2009)

However, various roles of Sarawak River had affected and depleted the natural water resources availability. Without any preservation efforts and proper management, the day may come when scarcity of water will pose a problem for Kuching city, even though the annual precipitation reaches 4,000 $\mathrm{mm}$.Meanwhile, the population of Kuching is projected to grow over one million by 2030 KTA Sarawak, 2009. In addition, tourism and industrial developments in the state capital are estimated to require additional treated water. The water demand was found growing fast with the increment of over 8\% per year KTA Sarawak, 2009, due to more newly developed areas are connected to the water reticulation system.

The current water supply for domestic and industrial used in Kuching City and surrounding areas are mostly provided by the reservoir at Batu Kitang. However, this reservoir has maximum capacity of 786 MLD (Morison et al., 2010), while the current demand for water in Kuching alone is 635 MLD. The current amount of water supply from the Batu Kitang area will soon outstretch its optimum stable supply capacity, where it is not sufficient to meet the demands from population growth, tourism and agricultural development.

In order to ensure the secure water supplies for Kuching City and its surrounding until the year 2030, a few studies were accomplished to develop Kuching Water Supply Master Plan between 1983 and 2000. These studies were carried out to find the alternatives that will incorporate into the Kuching Water Supply Master Plan Study. Following are the review of the alternatives that have been implemented for managing Sarawak River basin in order to increase the safe yield of raw water supply.
Sarawak river basin: Sarawak Basin is located in southwest of Borneo. The catchment area for Sarawak Basin is approximately $2459 \mathrm{~km}^{2}$ (DID, 2010a), covers the area from estuary (Muara Tebas) to upper catchments. The main river in Sarawak Basin is Sarawak River. The river originates from Kapuas Mountains, which is near to Indonesia international boundary. The river flows approximately $120 \mathrm{~km}$ (DID, 2010a) and divided into 2 main tributaries named as Sungai Sarawak Kanan dan Sungai Sarawak Kiri (refer Fig. 1). Some of the important tributaries are the Kuap River, Tengah River, Maong river, Bintangor river and Padungan river.

The biggest city on the river is Kuching, including Kuching North and Kuching South. The other major settlements are Padawan, $7^{\text {th }}$ miles town, $12^{\text {th }}$ mile town. The famous Kuching International Airport and Borneo Convention Centre are located within Sarawak Basin. Three major towns located at upstream of Sarawak River are Bau, Batu Kawa and the historical Siniawan.

\section{MATERIALS AND METHODS}

The main current water source is located at BKWTP. Since the commission of first module in year 1957, expansion works on the water treatment plants have progressively increased and the capacity of the water treatment works are extended to meet increased demand. However, the water source at Batu Kitang is still unable to meet the rapid increment of treated water demand. 


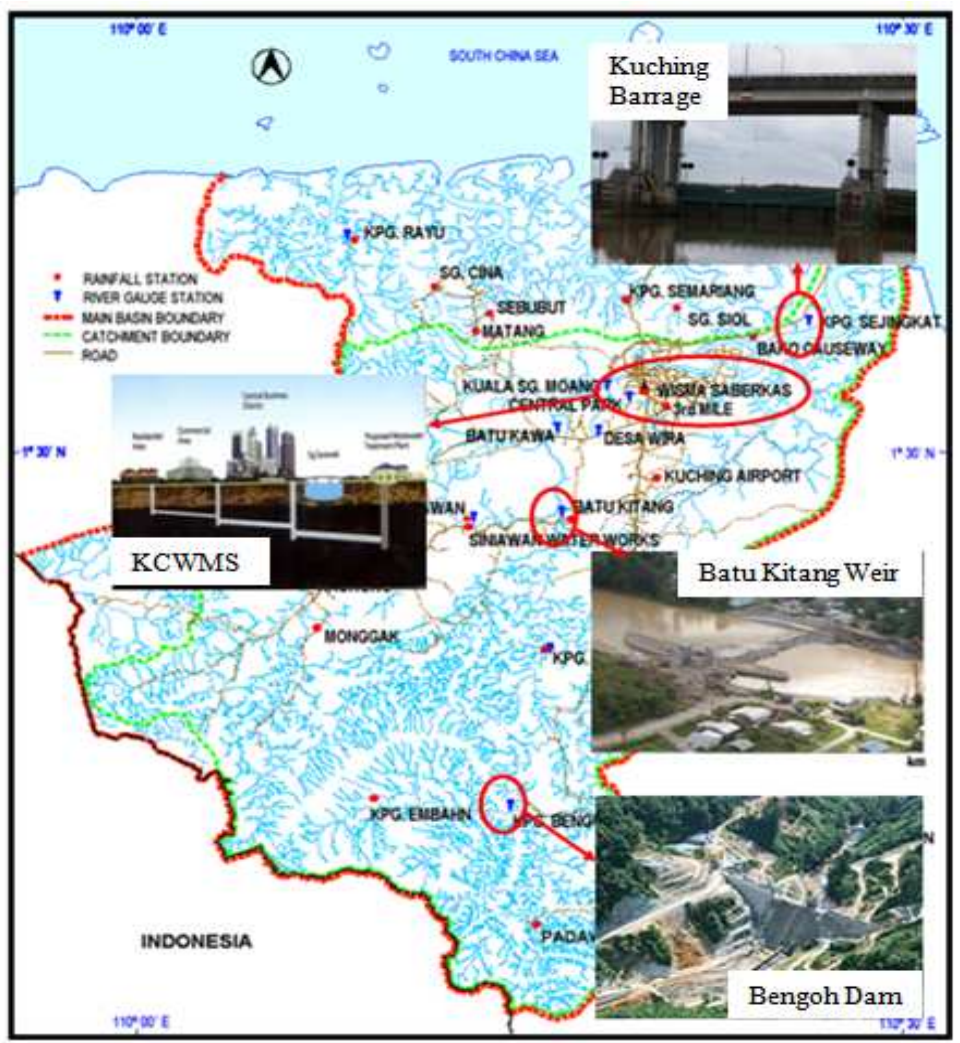

Fig. 2: The location of Bengoh Dam, Submersible Batu Kitang Weir, KCWMS, Kuching Barrage and Shiplock within Sarawak River Basin (DID, 2010a)

According Morison et al. (2010), the raw water demand in BKWTP for year 2010 is about 635 Mega Litres Per Day (MLD) and the treated water demand is about 603MLD. Due to the population increment in Kuching, the estimated raw and treated water demand is expected to increase to 2,047MLD and 1,945MLD respectively at year 2030. The projected of raw and treated water demand from year 2010-2030 for Kuching and surrounding areas are tabulated in Table 1.

Therefore, a few alternatives are considered and implemented to supplement or increase the safe yield of Sungai Sarawak Kiri. Currently, 4 alternatives have been implemented named as construction of $1.5 \mathrm{~m}$ height storage weir across Sungai Sarawak Kiri river channel, Kuching Barrage and Shiplock, Bengoh Dam and Kuching Centralized Wastewater Management System (KCWMS). The location of each project is illustrated in Fig. 2, along Sarawak River.

\section{RESULTS AND DISCUSSION}

Batu kitang water treatment plant: The Batu Kitang Treatment Plant (BKWTP) is located at Sungai Sarawak Kiri, about 40 miles from the sea. According to Kuching Water Board 2010, BKWTP currently supplies for more than $98 \%$ of the total water production for Kuching City.

Currently, raw water is pumped from Sungai Sarawak Kiri River to the Treatment Plant from four intakes as presented in Fig. 3. The raw water will undergo the conventional treatment process of coagulation, flocculation, sedimentation, filtration, disinfection and $\mathrm{pH}$ adjustment before supplying to the consumers.

The first Batu Kitang Water Treatment plant was commissioned in year 1957. Since then, the maximum capacity and number of treatment plant at BKWTP are upgraded, expanded and increased from time to time according to water demand. The improvement works are including changing the pump impeller, replace outdated submersible pump sets, booster pump sets, back rack screens for debris removal and dislodging systems at intakes and upgrading of standby power generator. Currently, there are totally 4 water treatment plants and 7 modules with total capacity of 480 MLD. Module 8 is still currently under construction. The maximum capacity of each treatment plants is presented in Table 2. 
Batu kitang submersible weir: In order to increase the safe yield of Sungai Sarawak Kiri and to ensure reliable supply of the water supply system, a $1.5 \mathrm{~m}$ height storage weir was constructed across the river together with a screw down gates and a double locked gate. The weir is located at the downstream of Batu Kitang Water Treatment Plant and start operating since July 2005 . The weir can raise the water level up to $1.5 \mathrm{~m}$ height. The weir was constructed using 2 sizes of amour rock. The top 1.2 $\mathrm{m}$ of the weir was filled with $0.6 \mathrm{~m}$ diameter armour stone. Where else, $1.4 \mathrm{~m}$ diameter amour stone was used to construct the lower part of submersible weir. Figure 4 presents the submersible weir at Sungai Sarawak Kiri. The screw down gates is to flush out the excess water from upstream to downstream. Meanwhile, double locked gate is for navigation purpose, to enable small boat travelling from upstream to downstream or vice versa.

Apart from increasing the safe yield, Batu Kitang submersible weir is also function as salinity barrier to prevent saline intrusion reaching into the water intakes. Figure 5 shows the flow versus demand verses yield of Sungai Sarawak Kiri from year 1998-2020. Figure 5 clearly indicated that with the construction of $1.5 \mathrm{~m}$ height weir across Sungai Sarawak Kiri, the flow has increased from 3.6-5.6 $\mathrm{m}^{3} \mathrm{sec}^{-1}$.

Kuching barrage and shiplock: Sungai Sarawak Regulation Scheme (SSRS) was completed in year 2000. SSRS involves closure of the river by 2 rockfilled causeways, construction of a tidal exclusion barrage with integral ship locking facility and a bridge over the barrage (refer to Fig. 6). This project incorporates a 3-in-1 infrastructure (barrage, shiplock and bridge), which is the first of its kind in Southeast Asia. The construction of Kuching Barrage will control the river water level to minimize the flooding risk in Sarawak Catchment. This is because the water level of upstream is fully control by Kuching Barrage after construction of Pending and Bako causeways (refer to Fig. 7).

The main objectives of the SSRS are:

- To provide transportation links between Sejingkat and Pending areas

- To secure and protect Kuching water supply and maintain the water quality at upstream by controlling the saline intrusion into upstream reaches of Sg. Sarawak

- To regulate the river water level upstream of the barrage

- To reduce the transport of muddy sediments to the foreshores of Santubong and Damai
- To mitigate fluvial and tidal flooding in Kuching by operating the barrage gate

Table 1: Projected water demand for Kuching and surrounding areas (Morison et al., 2010).

\begin{tabular}{lll}
\hline & Treated Water & Raw Water \\
Year & Demand (MLD) & Demand (MLD) \\
\hline 2005 & 389 & 410 \\
2010 & 603 & 635 \\
2015 & 874 & 920 \\
2020 & 1,265 & 1,332 \\
2025 & 1,568 & 1,651 \\
2030 & 1,945 & 2,047 \\
\hline
\end{tabular}

Table 2: Maximum capacity of treatment plants in Kuching Kuching Water Board, 2010

\begin{tabular}{|c|c|c|c|}
\hline Name of water treatment plant & $\begin{array}{l}\text { Year } \\
\text { Comm } \\
\text { issioned }\end{array}$ & $\begin{array}{l}\text { Maximum } \\
\text { Capacity } \\
\text { (MLD) }\end{array}$ & Modules \\
\hline Batu kitang treatment plant no. 1 & 1957 & 68 & 1 and 2 \\
\hline Batu kitang treatment plant no. 2 & 1978 & 96 & 3 and 4 \\
\hline Batu kitang treatment plant No. 3 & 1994 & 200 & 5 and 6 \\
\hline Batu kitang treatment plant no. 4 & 2006 & 100 & 7 \\
\hline Matang treatment plant & 1966 & 16 & \\
\hline Total & 480 & & \\
\hline
\end{tabular}

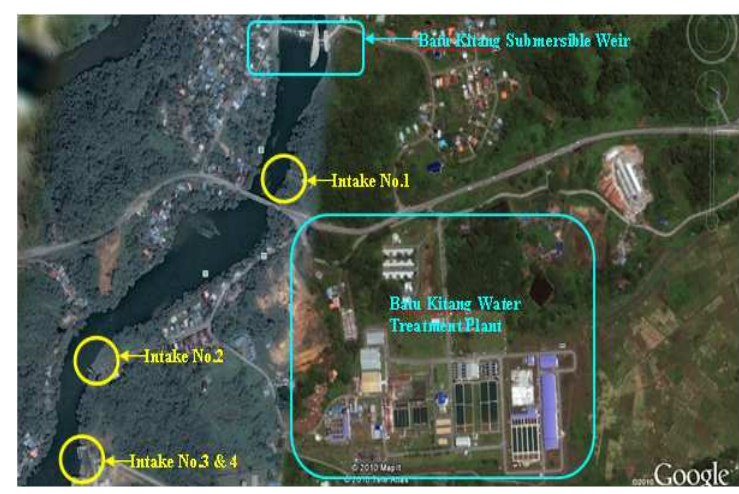

Fig. 3: Location of raw water intakes and submersible weir at BKWTP

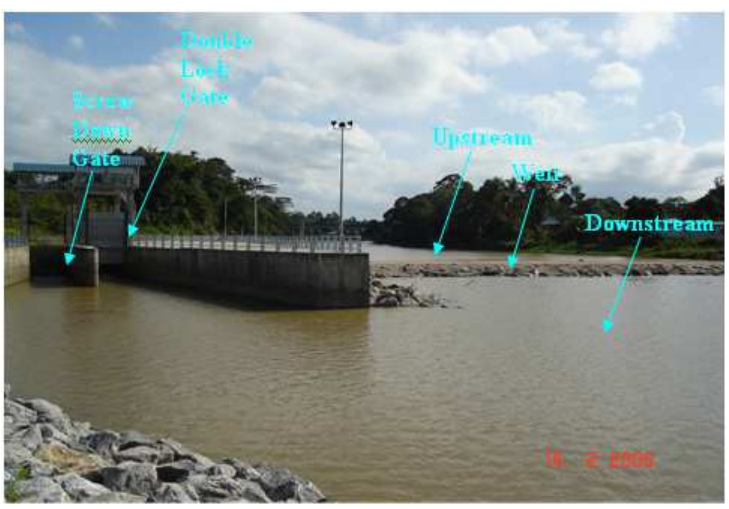

Fig. 4: Batu kitang submersible weir 
Am. J. Environ. Sci., 7 (3): 276-285, 2011

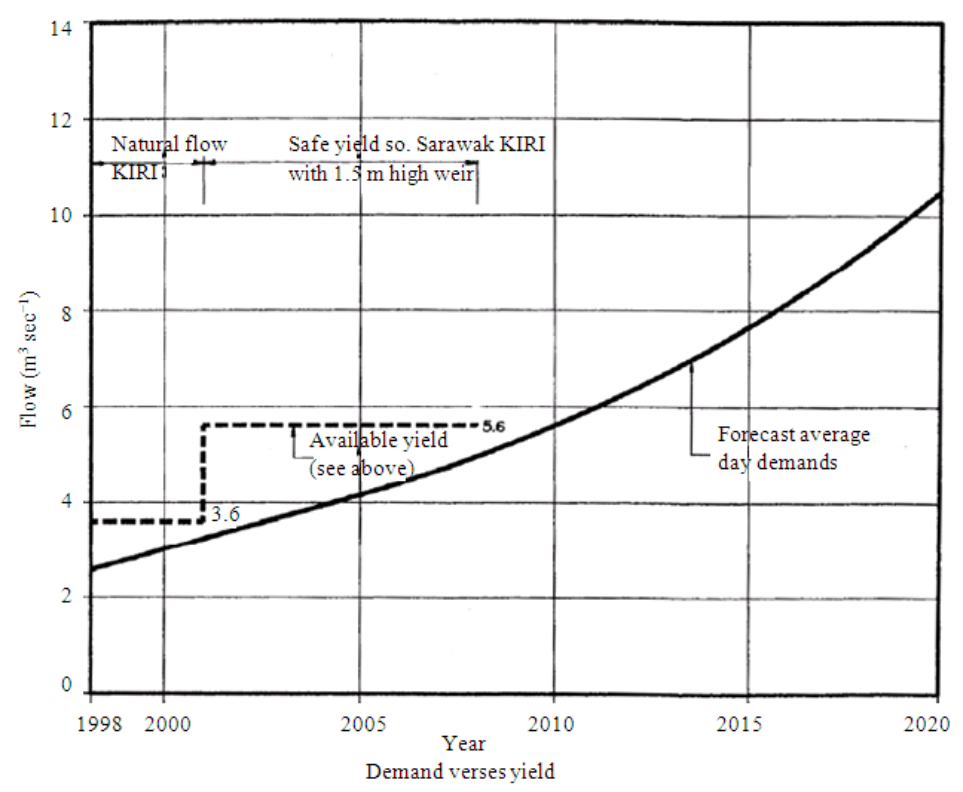

Fig. 5: Flow versus demand verses yield from year 1998-2020 for Sungai Sarawak Kiri (Yusuff el al., 2009)

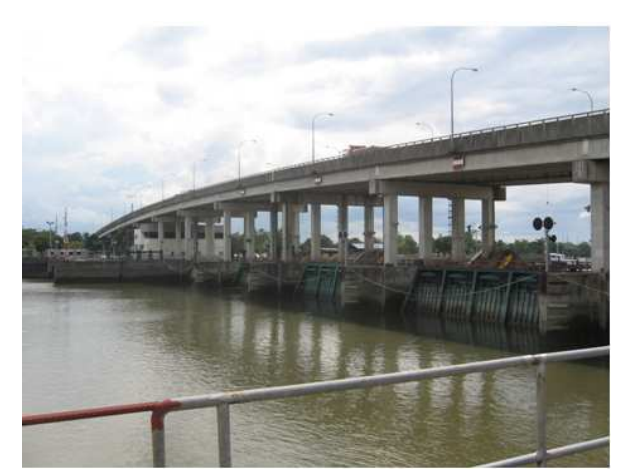

Fig. 6: Barrage radial gates and bridge

However, the proposed Scheme has affected shipping activity in Sarawak River. Hence, a shiplock is incorporated within the barrage for providing navigational access. Figure 6 presents the configuration of barrage gates. Barrage consists of 5 hydraulically operated radial gates with the width of $25 \mathrm{~m}$ each and 1 shiplock with 2 radial gates. The 5 gateways are used to control the water flow and the shiplock gate is for the passage of river traffic. Each barrage gate is approximately $168 \mathrm{~m}^{\text {tons }}{ }^{-1}$ and the shiplock gate is approximately $180 \mathrm{~m}^{-10 n s^{-1}}$. For most of the time, the regulated water level at upstream of Barrage is maintained at Land and Survey level of $+0.5 \mathrm{~m}$ except during flooding-in and total flush-out. The aim of flooding-in is mainly for ship repair, tributaries and drain flushing and it was carried out during high tide. Where else, total flush-out that carried out during low tide is to desilt the river upstream, flushing out silt and refreshing the river system.

The barrage is operated by Kuching Barrage Management (KBM). During raining season, all the Barrage gates have to be opened twice a day to flush out excess water for flood control. In contrast, the Barrage gates also need to be operated twice a day during dry season. This is to carry out low level flushing for the purpose of bringing saline head downward from Kuching Water Board raw water intake. Meanwhile, flooding in also has to be carried out once a week for cleaning the drains during dry season when drains get smelly. During normal time, barrage gates are operated to regulate water level for different purposes such as city drainage construction, river bank protection work and water sports.

Telemetry operation system: In order to regulate the river water level at upstream of the barrage during raining and dry seasons, the water level need to be monitored using telemetry system. Each telemetry station is equipped water level gauge and rainfall sensor to monitor water level and rainfall measurement at particular location. Rainfall and water level data collected will then be transmitted to Kuching Barrage Control Tower through Remote Radio Communication System (RRCS) at every $15 \mathrm{~min}$ interval. All the real time data will be displayed and monitored at Kuching Barrage Control Tower. Meanwhile, the telemetry station is also equipped with siren system. Once water level exceeded warning level, the siren alarm will be triggered to inform residents to evacuate. 
Currently, there are 24 rainfall and water level telemetry stations within Sarawak River catchment. The stations are Kpg Sandong, Kpg Bengoh, Kpg Skio, Kpg Blinbim, Kpg Siburuh, Kpg Bogag, Kpg Pedawan, Kpg Git, Kpg Landeh, Kpg Batu Kitang, Kpg Siniawan,
Buan Bidi, Bau JKR Water Treatment Plant, Kpg Grogo, Batu Kawa, Kpg Paroh, Taman Malihah, Taman Yen Yen, Satok Bridge, Kpg Segedup, SRB Chung Hua No.6, Sg. Maong Kanan, 2nd Link Bridge and Sg. Bintangor.

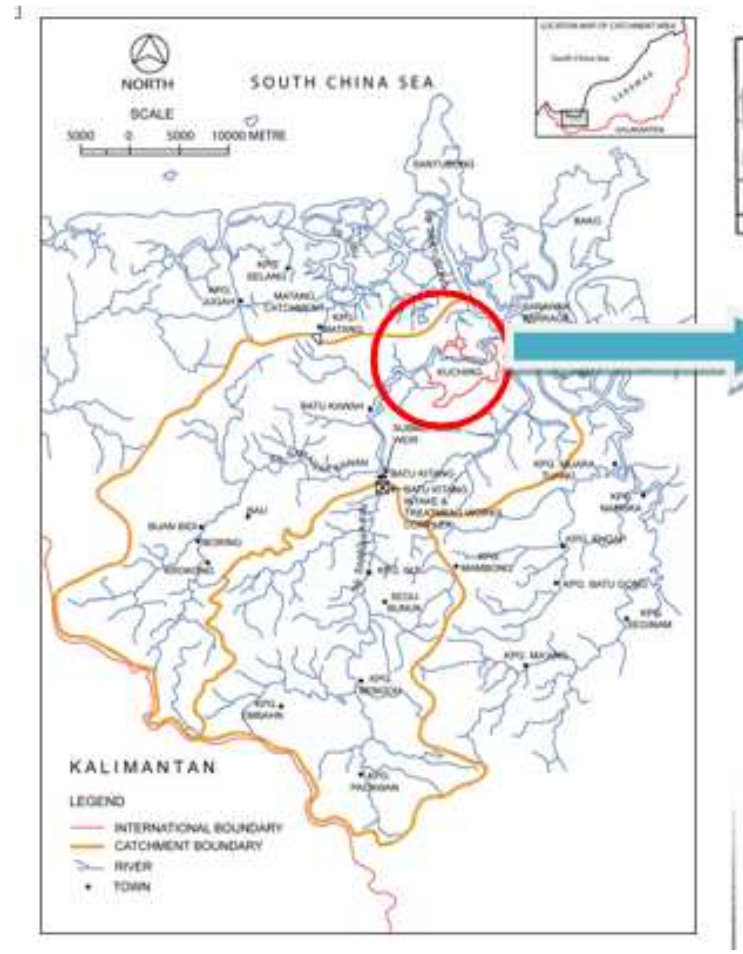

(a)

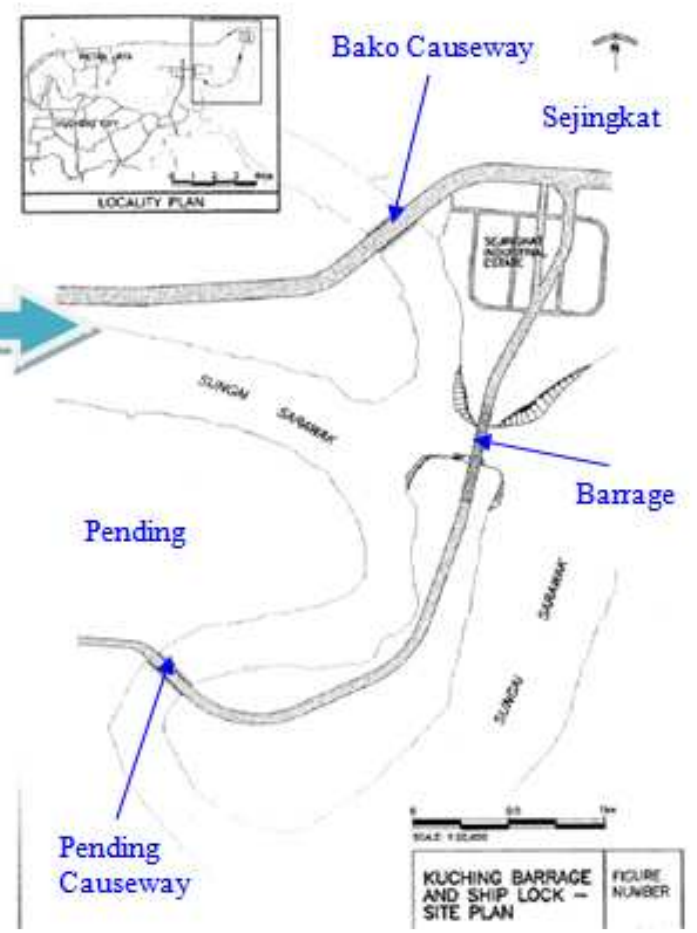

(b)

Fig. 7: Kuching Barrage and Shiplock (SRB, 2010). (a) The location of Kuching Barrage and Shiplock in Sarawak River Basin. (b) The location of Bako Causeway, Pending Causeway and Kuching Barrage and Shiplock

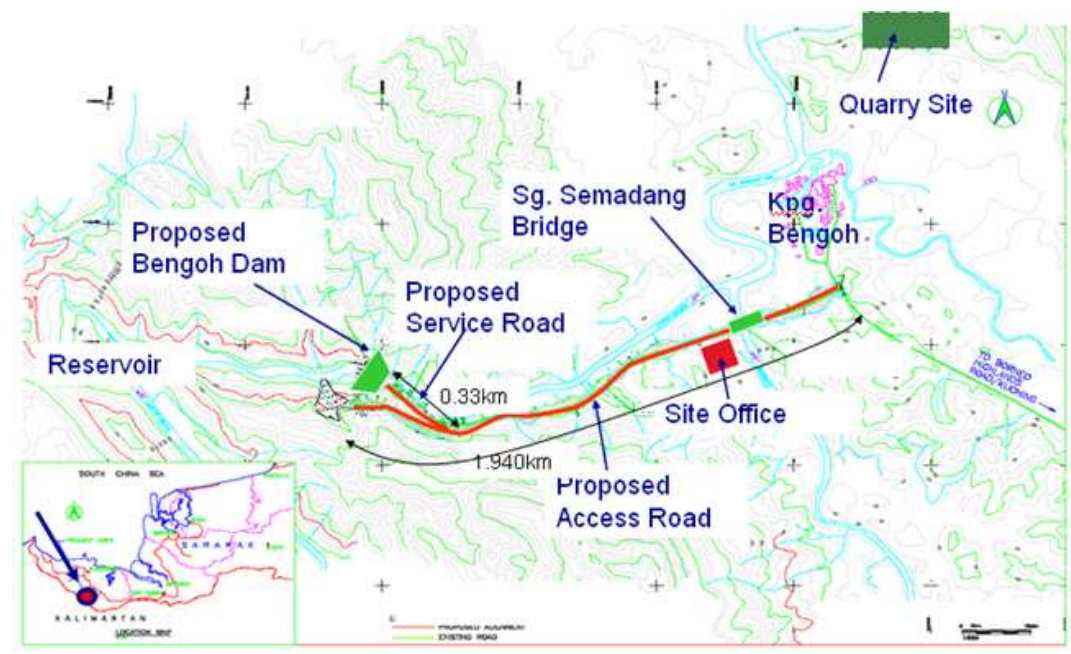

Fig. 8: Bengoh Dan catchment area and associate works Naim Cendera Sdn. Bhd, 2010 


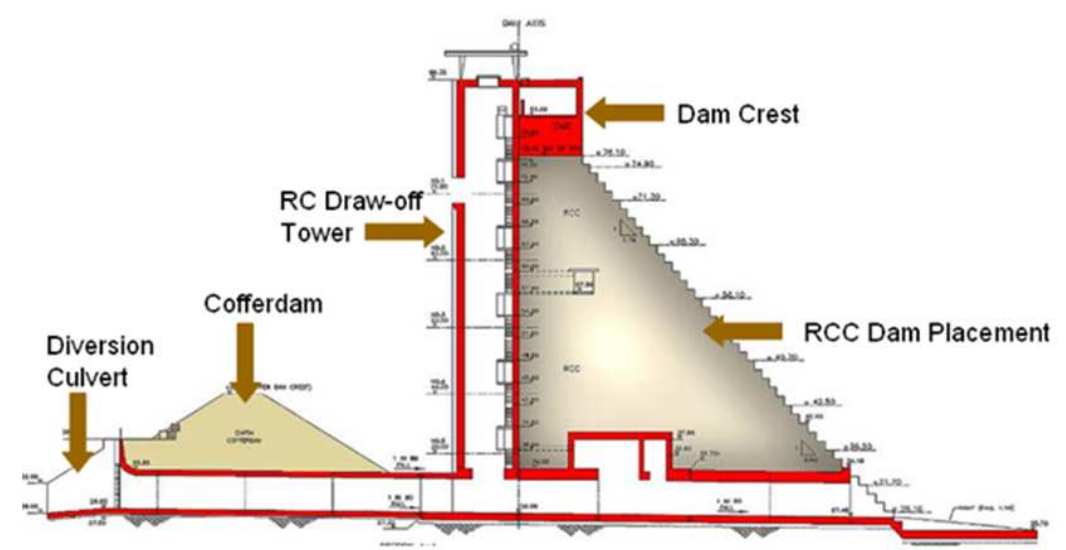

Fig. 9: Schematic diagram of Bengoh Dam Naim Cendera Sdn. Bhd. 2010

Bengoh dam: Bengoh Dam is located in a straight, narrow and steep stretch of the Bengoh River, a tributary upstream of Sungai Sarawak Kiri, about $1.5 \mathrm{~km}$ from Bengoh Village and $56.5 \mathrm{~km}$ from Kuching City. The purpose of constructing Bengoh Dam is to ensure secure adequate raw water is supplied to BKWTP during low river flows and low rainfall (Morison et al., 2010). The high quality water was stored by this dam as it is located at upper catchment of Sarawak River and far away from industrial area.

The Dam is expected to increase the safe yield of Sungai Sarawak Kiri that is sufficient to meet raw water demand projection up to year 2030. An estimated of 2047MLD (Morison et al., 2010) of raw water will be supplied to Batu Kitang Treatment Plant and this will benefit 1.7 million people. Bengoh Dam is constructed with Rolled Compact Concrete (RCC). Existing sound rock in the riverbed and valley formed a solid foundation for constructing Bengoh RCC dam. Other associate works involved are construction of draw off tower, spillway bridge and crest, valve chamber, dam drainage and grouting, river diversion, pipe works, mechanical and electrical works, dam operation office as shown in Fig. 8.

The schematic diagram of Bengoh Dam is illustrated in Fig. 9 and the dimensions are:

- $\quad$ Dam height $=63.2 \mathrm{~m} @ \mathrm{RL}=86.2 \mathrm{~m}$

- $\quad$ Dam length $=267 \mathrm{~m}$

- Dam volume $=160,000 \mathrm{~m}^{3}$

- $\quad$ Dam base width $=49 \mathrm{~m}$

The catchment area of Bengoh Dam is about $127 \mathrm{~km}^{2}$ (refer to Fig. 10), with full storage volume capacity of 144 million $\mathrm{m}^{3}$ of fresh water that will cover $8.77 \mathrm{~km}^{2}$ reservoir area (Morison et al., 2010). This amount is adequate to supply two months of fresh water even though there is zero rain to BKWTP from the year 2010 until 2030. This will increase the daily raw water production at the Batu Kitang treatment plant from 7862047 Mega Litres Per Day (MLD).

The Bengoh dam is designed as a gravity section to be stable under normal, extreme floods and seismic loads. The dam body facing upstream has a slope of $0.78: 1$ and facing downsteam at slope of $0.9: 1$ to reduce tensile loads at the foundation contact. The non-spillway section was made $8 \mathrm{~m}$ wide of RCC, that the strength was checked by finite element analysis. The total volume of RCC used is about $160,000 \mathrm{~m}^{3}$, plus $15,000 \mathrm{~m}^{3}$ of reinforced concrete in the diversion, outlet structures and spillway. The specified RCC strength is $15 \mathrm{MPa}$.

The river diversion was initially designed using twin box culverts with the size of $4 \mathrm{~m}$ wide by $4.5 \mathrm{~m}$ high each, located on a rock shelf on the dam left abutment. These twin box culverts are adequate to cater 1:10 year flood of $365 \mathrm{~m}^{3} \mathrm{sec}^{-1}$. A third similar opening was added in the dam body during construction stage to prevent backwater flooding of the existing villages located upstream of the dam, up to the 1:100 year flood Naim Cendera Sdn. Bhd, 2010.

An overflow spillway on the dam crest with a stepped downstream face was adopted, designed to pass the Probable Maximum Flood (PMF) without overtopping the dam crest, where the PMF peak inflow was determined as $2420 \mathrm{~m}^{3} \mathrm{sec}^{-1}$ (Morison et al., 2010). The intake takes the form of a dry well with inlets at five levels feeding a single $1.6 \mathrm{~m}$ diameter pipe stack above one of the diversion culverts. The pipe discharges to the downstream culvert through a hooded fixed-jet cone (Howell-Bunger) valve. A lifting Dshaped trash screen is placed in the gate track of the 
operating intakes. Each inlet is controlled by a gate valve with provision for an upstream maintenance gate.

Currently, Sarawak state government had already initiated 2 new rural development programs beside Bengoh Dam. After the impoundment, the storage reservoir area behind the dam will become a recreation centre and expected to promote tourism-based activities.

Kuching centralized wastewater treatment plant: Fig. 10 presents the water quality status for all rivers basins of Sarawak. Sarawak River basin is categorised as slightly polluted which is coloured in yellow. $\mathrm{Sg}$ Sarawak is classified as Class III (DID, 2010b). This is mainly because Kuching city which is populated with 658,549 residents in year 2010 does not have a modern wastewater management system in place. The current wastewater management is most of the black water are flushed and treated at individual septic tank that removes only about $40 \%$ of the pollutants excluding nutrients and bacteria. However, the grey water are discharged into the natural waterways such as monsoon drain and then Sarawak River together with stormwater. This partially treated and untreated water is a major contributor of pollution to Sarawak River, thus depleting the water quality especially during the dry flows.

Therefore, Kuching Centralized Wastewater Management System (KCWMS) is implemented to collect wastewater within Sarawak River catchment and to treat the wastewater at a centralized plant before discharging into the natural waterways. Before implementation of the project, river water quality modeling is investigated to indentify the Dissolved Oxygen (DO) level in Sarawak River Jurutera Jasa Sarawak Sdn. Bhd, 2010. Modeling results are compared among a) scenario (1) without any centralized management system; (b) scenario (2) with the completion of package 1 of KCWMS; (c) scenario (3) with the completion of packages 1, 2, 3 and 4 of KCWMS.

Figure 11 presents the water quality modeling results obtained for Sarawak River. 10 gauging points are selected along Sarawak River to measure the Dissolved Oxygen (DO) for 1:50 year, 7-day drought with year 2010 pollutant loads. The selected gauging points are located at confluence, Batu Kawa Bridge, Sungai Tengah, Sungai Maong, Satok Bridge, Sungai Bintangor, Holiday Inn, Sungai Padungan, Wastewater Treatment Plant (WWTP) and Kuching Barrage.

The water quality modeling indicated that without the construction of centralized wastewater treatment system in Kuching, the DO level will reduce to as low as $0.5 \mathrm{mg} \mathrm{L}^{-1}$ (indicated with red line in Fig. 12) especially along Sungai Bintangor, Holiday Inn and Sungai Padungan. The modeling results reveal that DO level is slightly improve to $1.5 \mathrm{mg} \mathrm{L}^{-1}$ (indicated with blue line in Fig. 12) along Sungai Bintangor, Holiday Inn and Sungai Padungan with the completion of Package 1 of KCWMS.

The modeling results also reveal that with the completion of Package 1, 2, 3 and 4 of KCWMS, Sarawak River will be rehabilitated and thus sustain marine life as indicated by green line in Fig. 12.

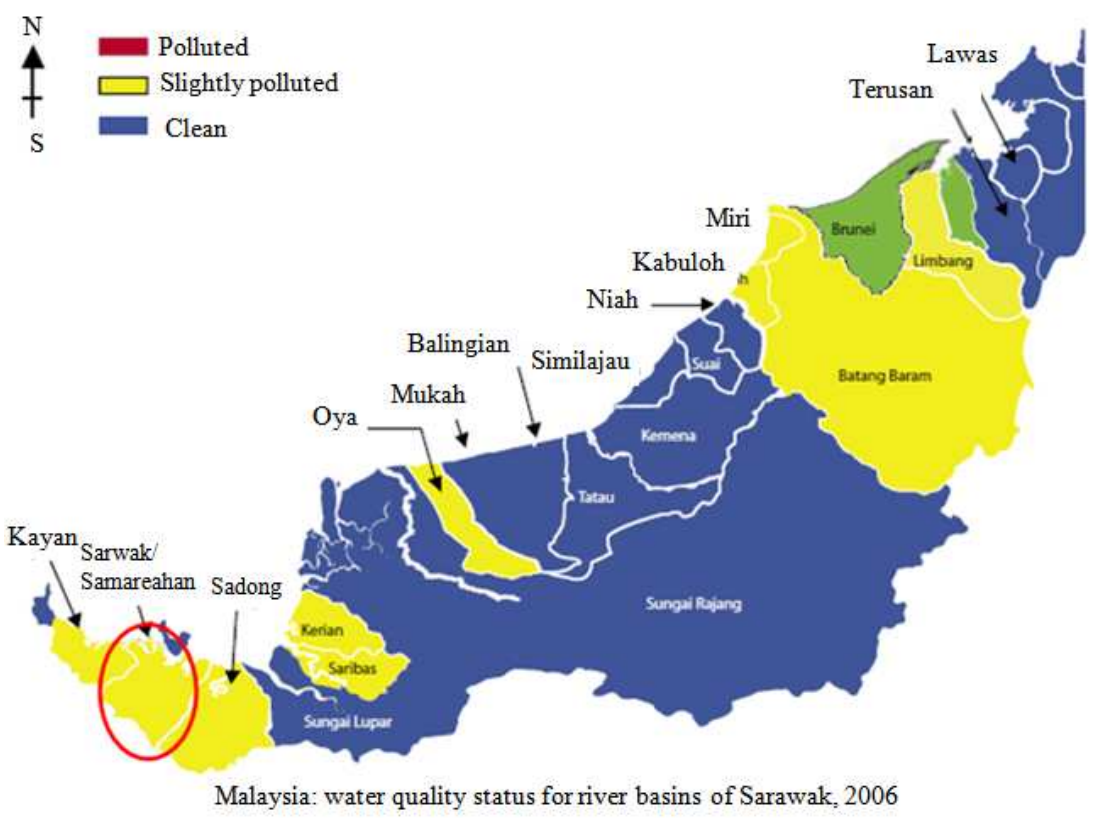

Fig. 10: Water quality status for all rivers basins in Sarawak (Mohebi and Rahim, 2010) 


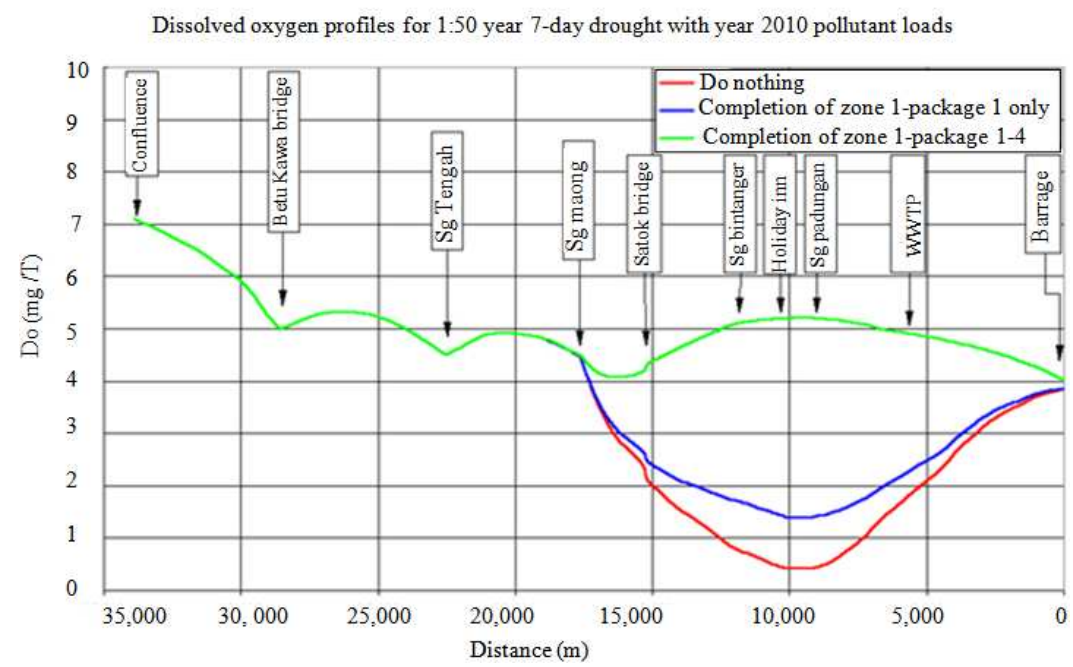

Fig. 11: Sarawak River DO level without any centralized management system (red line), completion of package 1 of KCWMS (blue line), completion of packages 1,2,3 and 4 of KCWMS (green line) Jurutera Jasa Sarawak Sdn. Bhd, 2010

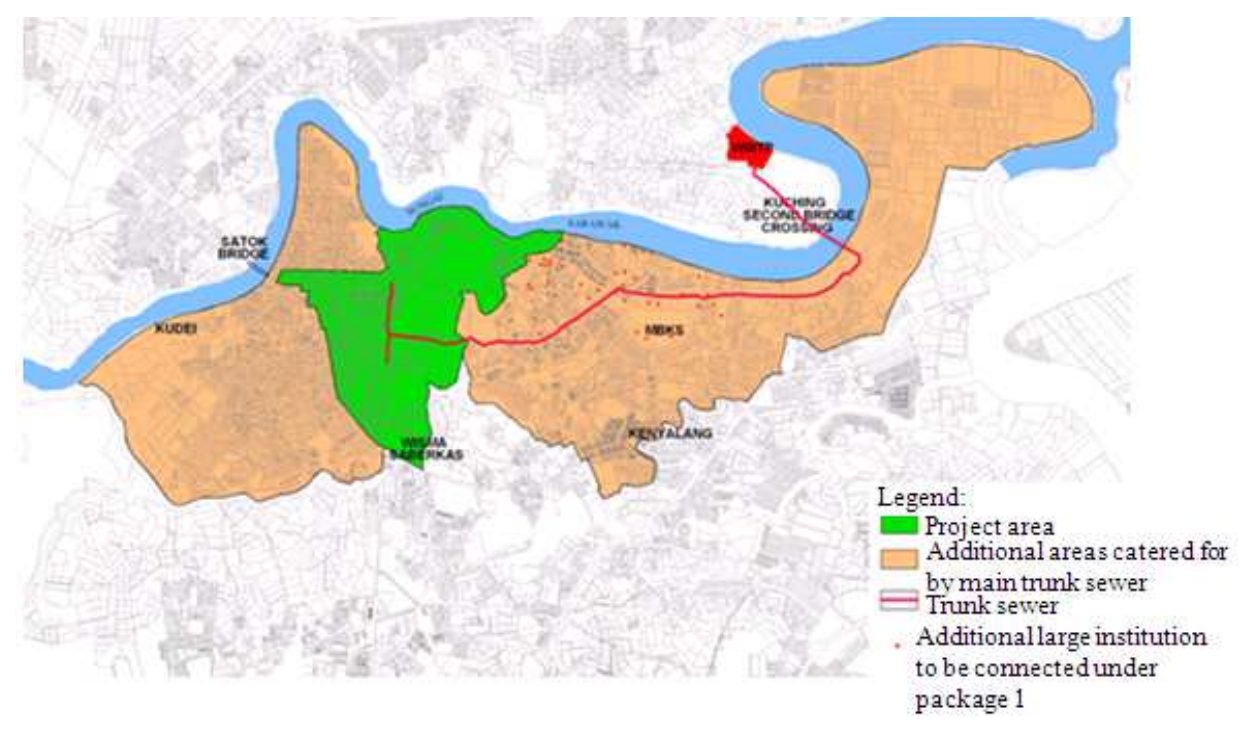

Fig. 12: Areas covered by Package 1 of KCWMS (Jurutera Jasa Sarawak, 2010)

The scope of work of KCWMS involves collect wastewater including black and grey water from all properties such as residential houses, shophouses, shopping complex, hotels will be connected using reticulation sewer (Hussain et al., 2010). The wastewater was transported to centralized Waste Water Treatment Plant (WWTP) through sewer trunk. The Sewer Network is designed based on true gravity flow system.

Meanwhile, trenchless technology was adopted to lay deep sewer pipes. Apart from reducing traffic disruption, trenchless technology is also able to reduce utility relocations, reduce ground water lowering and thus reducing ground subsidence problems.

In general, KCWMS was divided into 4 packages named as package 1, 2, 3 and 4. Each package is sized to cater for 100,000 Population Equivalent (PE), thus 400,000 PE for 4 packages (SSDS, 2010).

The WWTP for package 1 is able to cater for $100,000 \mathrm{PE}$ and is designed to last until 2030. WWTP is located on a 10.9 hectares site (refer to Fig. 12), sufficient for future expansion for constructing 4 WWTP that will achieve the final capacity of 400,000 PE. The proposed wastewater 
treatment method is activated sludge system. Treated effluent from WWTP shall comply with Standard A of the Environmental Quality Act requirement (Karami et al., 2009), that is equivalent with drinking water quality standard before discharging into Sarawak River.

The treated water is expected to be used by domestic, industries and irrigation purposes and thus increases the water resources in Sarawak River catchment. Treated Sludge that composed of $20 \%$ of dry solids are disposed at Mambong Sanitary landfill (Salimin et al., 2010).

Trenchless method such as Tunnel Boring Machines is adopted to install the sewer pipeline that ranges from 225-1500 $\mathrm{mm}$ in diameter. The massive underground tunnel would have a total length of $64.4 \mathrm{~km}$ with a depth of between 6 and $27 \mathrm{~m}$ (SSDS, 2010). Existing septic tanks or package plants will be disinfected and decommissioned once the trunk sewer, secondary and tertiary sewers are connected to each household.

\section{CONCLUSION}

The Sarawak government has constructed a few hydraulic structures along Sarawak River to secure sufficient water sources for meeting the ever increasing demand. The raw water source supplied to BKWTP without constructing any hydraulic structure can last until year 2005. With the construction of submersible weir at Batu Kitang, the raw water source have increased to 786 MLD that can last until year 2010. Meanwhile, Kuching Barrage and shiplock was also commissioned in year 2000 for preventing saline intrusion reaches upper catchment that will degrade the water quality and to regulate the water level at upper catchment. Meanwhile, Bengoh Dam was completed in year 2010. The storage reservoir behind the dam will ensure sufficient water will be supply to Batu Kitang Water Treatment Plant until year 2030. Meanwhile, KCWMS will treat black and grey water to Standard A quality before releasing into Sarawak River. Beside rehabilitate and restore the contaminated rivers such as Bintangor and Maong Rivers and prolong marine life, the treated Standard A quality water can also be supplied for domestic, industrial and irrigation used and thus increased the water source in Sarawak River.

Meanwhile, there are further plans for conserving and securing water after the year 2030. A few alternatives had been considered and identified such as pumping additional supply from Sungai Sarawak Kanan catchments to Batu Kitang Water Treatment Plant, limited local potential for groundwater development, construction of a regulating reservoir in the Sungai Sarawak Kiri catchment and construction a dam at Sungai Sarawak Kanan.

Hopefully, with the proper planning and management of water resources in Sarawak River Basin, the water source is sufficient for fulfilling the ever increasing water demand and providing a sustainable living environment for Kuching City.

\section{REFERENCES}

Gandaseca, S., J. Sabang, O.H. Ahmed and N.M.A. Majid, 2009. Vegetation assessment of peat swamp forest using remote sensing. Am. J. Agric. Biol. Sci., 4: 167-172. DOI: 10.3844/AJABSSP.2009.167.172

Hussain, G., A. Alquwaizany and A. Al-Zarah, 2010. Guidelines for irrigation water quality and water management in The Kingdom of Saudi Arabia: An overview. J. Applied Sci., 10: 79-96. DOI: 10.3923/JAS.2010.79.96

Karami, B., K.N. Dhumal, M. Golabi and N. Jaafarzadeh, 2009. Optimization the relationship between water quality index and physical and chemical parameters of water in Bamdezh wetland, Iran. J. Applied Sci., 9: 3900-3905. DOI: 10.3923/JAS.2009.3900.3905

Mohebi, M. and K.A. Rahim, 2010. Revenue Determinants in Tourism Market. Am. J. Applied Sci., $\quad 7$ : 1593-1598. DOI: 10.3844/AJASSP.2010.1593.1598

Morison, A.C., R.K.W Ling and D.A. Rangu, 2010. Study and design aspects of bengoh dam, sarawak. Int. J. Hydropower Dams. 17: 49-54.

Salimin, M.I., S. Gandaseca, O.H. Ahmed and N.M.A. Majid, 2010. Comparison of selected chemical properties of peat swamp soil before and after timber harvesting. Am. J. Environ. Sci., 6: 164-167. DOI: 10.3844/AJESSP.2010.164.167

Yusuff, M.T.M., O.H. Ahmed and N.M.A. Majid, 2009. Effect of enhancing urea-humic acid mixture with refined acid sulphate soil. Am. J. Applied Sci., 6: 1892-1896.

DOI: 10.3844/AJASSP.2009.1892.1896 